\title{
Prioritizing the client trust factors in electronic banking using analytic hierarchy process
}

\author{
Hossein vazifedust ${ }^{*}$ and Mehdi Bani’Asadi
}

Department of Business Management, Science and Research Branch, Islamic Azad University, Tehran, Iran

\begin{tabular}{l}
\hline C H R O N I C L E \\
\hline Article history: \\
Received July 28, 2013 \\
Received in revised format \\
20 November 2013 \\
Accepted 14 January 2014 \\
Available online \\
February 20 2014 \\
\hline Keywords: \\
AHP \\
Analytical hierarchy process \\
Electronic Banking \\
Trust \\
Features of Trust
\end{tabular}

Article history:

20 November 2013

Accepted 14 January 2014

ailable online

Keywords:

Analytical hierarchy process

Trust

Features of Trust \begin{abstract}
A B S T R A C T
This paper prioritizes the trust factors among electronic banking clients of an Iranian bank named Parsian Bank. The study first analyzes and reviews the literature and interviews with experts of electronic banking and academicians and determines client trust as the most important factor for development of electronic banking. The study also determines different factors associated with trust, which includes individual factors, banking factors and infrastructural factors. The sample populations consist of 25 experts who are academicians, managers and bank officers, clients of electronic banking. The necessary data was collected through conducting interviews and questionnaires and they are analyzed using analytic hierarchy process (AHP). The research findings indicate that the attitudinal factors, telecommunication infrastructure and cultural factors were the most influential factors accordingly and the customer orientation and ease of access were the least influential factors.
\end{abstract}

\section{Introduction}

Nowadays, there is no doubt regarding the importance of easy communication, without geographical and physical limitations. In electronic banking the need for analyzing the information technology (IT) characteristics and parameters influencing trust of electronic banking clients are emphasized by all experts since we see a failure in such business activities in the absence of client trust. Therefore, banks have to detect all the parameters of this field in order to gain customers' trust particularly those who apply the electronic banking services. In this regard, there are multiple factors, which play essential role and trust is an important component of banking transactions (Bailey, 2002). Consequently, security and trust are always argued as the most important components for success of electronic banking.

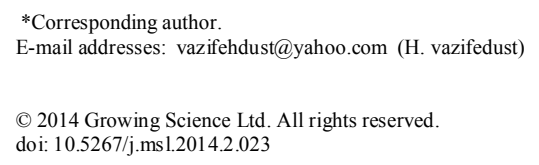


Electronic banking (e-banking) is a new method of banking, which provides different services in cyberspace. According to the previous studies, the key factors in accepting the e-banking are trust and customer satisfaction towards the bank, which indirectly influence the e-banking (Dobholkar, 2003.).

E-banking has different characteristics, which influence differently the success or failure of this industry. Reviewing the background of the study discloses that the previous related researches conduced have concentrated more on the aspects associated with development of electronic system in Iran from operational concepts perspective and theoretical discussions have been neglected. Therefore, in the present study we try to concentrate more deeply on theoretical areas of e-banking, barriers in gaining the client trust in an Iranian bank named Parsian Bank, which is the fundamental component of developing e-banking system. The proposed study of this paper defines the individual, banking and infrastructural variables on client trust in e-banking in Parsian Bank. It also ranks client trust variables for e-banking customers of Parsian Bank.

\section{Literature Review}

The concept of trust dates bank to the history of human life and beginning of interpersonal social interactions. Almost every aspect of an individual's life is based on trust and it can be defined as a belief in the character, or truth of individual or thing. Some definitions of trust are:

Mayer defines trust as the wish of a party to be vulnerable to the actions of another party based on the expectation that the trustee intends and is capable to execute in ways, which would not harm the trust or in a particular circumstances to control the trustee's behavior. Rousseau et al. (1998) defines trust as a psychological state including the intention to accept vulnerability based on positive expectations of the intention or behavior of another. According to Bailey (2002), trust consists of four main principles,

- Competency is a cluster of related abilities, commitments, knowledge and skills, which enables a person to act effectively in a job or situation. In other words, we call a person competent when we believe he/she is capable of performing the assigned tasks and providing the expected services.

- Benevolence is a belief, which express the seller desires to serve customers, well and he/she does not act only for the profit and his/her self-interest.

- Predictability is belief in behavioral stability of the other party.

- Honesty expresses the fact that the person believes that the trustee act sincerely and adhere a set of principles and standards in his/her behavior (Wang \& Emurian, 2005). The following presents the four characteristics of trust (competency, benevolence, predictability, and honesty), which have been identified in previous studies.

\begin{tabular}{lcccc}
\hline \multirow{2}{*}{ Researcher } & \multicolumn{3}{c}{ Features of Trust } \\
\cline { 2 - 4 } & Honesty & Predictability & Benevolence & Competency \\
\hline Ang et al., 2005 & $\sqrt{ }$ & $\sqrt{ }$ & $\sqrt{ }$ \\
Danny \& Canoon 1997 & $\sqrt{ }$ & $\sqrt{ }$ & \\
Geffen \& Govindaraiulu, 2001 & $\sqrt{ }$ & $\sqrt{ }$ \\
Lee \& Turban, 2001 & $\sqrt{ }$ & $\sqrt{ }$ \\
Mayer et al., 1995 & $\sqrt{ }$ & & \\
\hline
\end{tabular}

Geffen and Govindaraiulu (2001) investigated the trust based on a multidimensional attitude in ecommerce and reported that competency, benevolence and honesty were the prerequisites for creating trust in e-commerce. Ang et al. (2001) presented three influential principles for increasing the perception of trust in Internet.

1. The ability of the seller to deliver the good or service as promised.

2. The tendency of e-seller to rectify his action when the transaction is not satisfactory for the customer.

3. Existence of customer privacy strategies and stating the same in the web site. 
Lee and Turban (2002) state four elements influencing on the trust of the customers in e-purchases.

1- Trustworthiness of e-seller,

2- Reliability of Internet as a medium in e-purchases,

3- Infrastructural elements such as approval of other companies,

4- Other factors like the size of the company.

Hemphill emphasized the necessity of legalizing and adoption of civil solutions for building trust in electronic customers. He proposed the following items as a principal of building trust among ecustomers;

1- Setting guidelines and policies by seller regarding non-disclosure of customers' personal information,

2- Providing the customers the right to choose how their personal information are used by the seller,

3- Allowing customers to access and view their personal data.

Egger (2000) proposed the model of trust in e-commerce in order to gain an understanding of effective factors assessing the level of seller trustworthiness in e-purchase. He categorized these factors in seven subcomponents, which are as follows,

1- Transference can be defined as creating trust for customers regarding specific website via a third party.

2- Reputation refers to the strength of a trademark.

3- Familiarity refers to ease of access and using a website.

4- View refers to the layout and design of a website.

5- Risk refers to the risks pertaining in e-payment and the aftersales service offered to the customer.

6- Cooperation refers to the level of communication and interaction between consumer and the company.

7- Transparency refers how the company treats and uses the customers' information.

\section{Materials and Methods}

We use the following conceptual model of the present study.

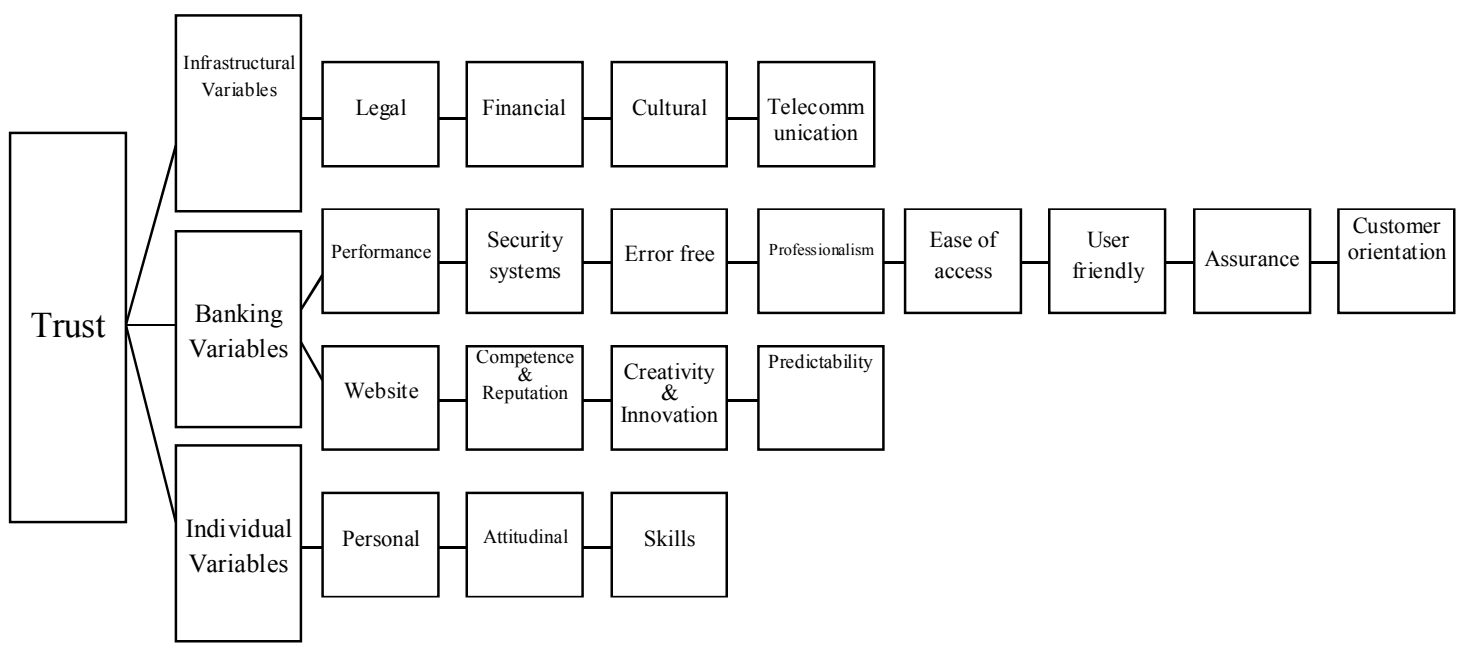

Fig. 1. Conceptual model of the study

(Adapted from Wendy et al. 2005)

This Model includes the following aspect; 
- Individual Variable: These variables study the factors of gaining client trust from the customers' point of view and address whatever characteristics, which lead to clients trust toward the electronic banking.

- Banking variables: These variables analyze the factors of gaining client trust from the bank perspective and emphasize those banking features, which lead to customers trust toward the electronic banking.

- Infrastructural variables: These variables investigates the factors of gaining client trust from ebanking macro and infrastructural perspective, in other word, it addresses the almost all essential factors, which lead to development and growth of e-banking system.

\begin{tabular}{|c|c|c|}
\hline $\begin{array}{l}\text { Individual } \\
\text { Variables }\end{array}$ & \multicolumn{2}{|r|}{$\begin{array}{l}\text { Personality: It refers to all factors related to individuals' personality such as risk taking } \\
\text { level, familiarity with cyber space and lack of time for the mental, and career } \\
\text { preoccupations (Corbitt et al., 2003). }\end{array}$} \\
\hline \multirow{2}{*}{$\begin{array}{l}\text { Wang \& } \\
\text { Emurian, } \\
2005\end{array}$} & \multirow{2}{*}{\multicolumn{2}{|c|}{$\begin{array}{l}\text { Attitudinal: It refers to the attitude of customers toward using e-services such as no } \\
\text { preference of using traditional tools instead of e-tools and his past experiences (Wang et } \\
\text { al, 2005). } \\
\text { Skill: It refers to the level of customer's familiarity with e-commerce and his } \\
\text { satisfaction derived from experiences in this regard (Yoon, 2002). }\end{array}$}} \\
\hline & & \\
\hline \multirow{10}{*}{$\begin{array}{l}\text { Banking } \\
\text { Variables } \\
\text { (Yoon, 2002) }\end{array}$} & \multirow{7}{*}{  } & $\begin{array}{l}\text { Security system: It refers to the various technologies provided in order to create, } \\
\text { establish and protect customers trust in e-banking, such as cryptography, seal \& } \\
\text { signature verification (Wang \& Emurian, 2005). }\end{array}$ \\
\hline & & $\begin{array}{l}\text { Error free system: Customers expect error free website such as incorrect } \\
\text { information, wrong processing, disconnections of services, therefore if the } \\
\text { website errors are few the level of customer satisfaction would increase. }\end{array}$ \\
\hline & & $\begin{array}{l}\text { Professionalism: This aspect of the model of Wang and Emurian (2005) refers to } \\
\text { the design factors and graphic interface, which customers initially encounter. }\end{array}$ \\
\hline & & $\begin{array}{l}\text { User friendliness: It refers to the existence of appropriate helps and guidance in } \\
\text { the website (Egger, 2003). }\end{array}$ \\
\hline & & $\begin{array}{l}\text { Customer oriented: It refers to existence of appropriate guidelines for customers } \\
\text { when using the website (Sultan et al. 2000). }\end{array}$ \\
\hline & & $\begin{array}{l}\text { Assurance: It refers to providing \& presenting the approvals obtained from credit } \\
\text { agencies in their agencies and the possibility of transactions monitoring by } \\
\text { customers (Kim et al. 2004). }\end{array}$ \\
\hline & & $\begin{array}{l}\text { Ease of access: It refers to convenience of using the Website (Wang \& Emurian, } \\
\text { 2005). }\end{array}$ \\
\hline & \multirow{3}{*}{ 光芯 } & $\begin{array}{l}\text { Competency \& Reputation: It refers to belief in abilities, skills, and banking } \\
\text { expertise in e-banking (Geffen, } 2002 \text { and Yoon, 2002). }\end{array}$ \\
\hline & & $\begin{array}{l}\text { Creativity \& Innovation: It refers to innovative aspects, updated services and } \\
\text { employing modern technologies by bank to facilitate the customers banking } \\
\text { services (Kim et al, 2004). }\end{array}$ \\
\hline & & $\begin{array}{l}\text { Predictability: It refers to the level of banks stability in providing and offering e- } \\
\text { services (Shankar et al, 2002). }\end{array}$ \\
\hline \multirow{4}{*}{$\begin{array}{l}\text { Infrastructura } \\
1 \text { Variables }\end{array}$} & \multicolumn{2}{|r|}{$\begin{array}{l}\text { Telecommunication: It refers to banks telecommunication structure, which provides } \\
\text { terminal equipment connections. Regarding the technical and telecommunication } \\
\text { infrastructures, most of the bank branches possess ports and bank connects to central } \\
\text { bank via different methods (Dialup, satellite etc.) }\end{array}$} \\
\hline & \multicolumn{2}{|r|}{$\begin{array}{l}\text { Legal: Hemphill's study emphasizes on the existence of appropriate legal infrastructures } \\
\text { and framework in e-banking cyber space (Hemphill, 2002). }\end{array}$} \\
\hline & \multicolumn{2}{|r|}{$\begin{array}{l}\text { Financial: It refers to supply of financial resources for financing investments in } \\
\text { telecommunication, expenditure related to development of satellite-computer networks } \\
\text { and costs related to access to web and updating the networks. }\end{array}$} \\
\hline & \multicolumn{2}{|r|}{$\begin{array}{l}\text { Cultural: It refers whether the e-banking possess an appropriate place between people, } \\
\text { bank and government, such as familiarity of managers and government officials to e- } \\
\text { banking issues, and the high digital literacy level of society and the appropriate supports } \\
\text { of private banks as the main agents of development of e-banking in Iran. }\end{array}$} \\
\hline
\end{tabular}

Based on the conceptual model in Fig. 1, the following questions are proposed; 
1. To what extent the individual variables influence the level of e-client trust of Parsian Bank?

2. To what extent the Banking variables influence the level of e-client trust of Parsian Bank?

3. To what extent the infrastructural variables influence the level of e-client trust of Parsian Bank?

4. How is the prioritizing of the trust variables of e-customers of Parsian Bank?

The current study is of qualitative type and the data collection is accomplished through conducting survey. The sample size is 25 , which consists of university teachers, managers and e-banking experts in different branches of Parsian Bank and the customers who use the bank's e-services in Tehran. The data collected analyzed using Analytic Hierarchy Process (AHP), Expert Choice and Microsoft Excel Software. The questionnaire items adopted from three articles and customized according to social environment and in this regard, we used the reverse translation method. In the present paper some indices used in the questionnaire for assessing trust variables which include Attitude, Cooperation and Transparency.

\subsection{Data Analysis}

In order to analysis the data, the first step is to calculate the compatibility rate of all paired comparison matrices in AHP, because if in a decision making case the number of decision makers (Experts) are more than one, in order to consider the opinion of all participants, we should use group AHP (Saaty, 1990). In this cases we can use the geometric mean for the elements of comparison matrices, $\mathrm{a}_{\mathrm{ij}}=\left(\prod_{1}^{\mathrm{k}} \mathrm{a}_{\mathrm{ij}}\right)^{1 / \mathrm{k}}$ and the opinion of decision makers will be imported in group calculation when the compatibility rate of each opinion is not below 0.1 . Table 1 presents details of our calculations to obtain acceptable compatibility. As can observe from the results, we should revise the table of comparisons. According to Saaty (1994), the compatibility index for group comparisons is defined as follows,

Table 1

The results of consistency ratios

\begin{tabular}{lccccc}
\hline & \multicolumn{5}{c}{ Factors } \\
\cline { 2 - 6 } Matrices & $\mathrm{N}$ & $\lambda \max$ & $\mathrm{CI}$ & $\mathrm{RI}$ & $\mathrm{CR}$ \\
\hline General Variables & 3 & 3.0000008 & 0.000000 & 0.58 & 0.000000 \\
Individual Variables & 3 & 3.007838 & 0.002613 & 0.58 & 0.004505 \\
Banking Variables & 2 & - & - &. &. \\
Website related Variables & 7 & 7.2755 & 0.0394 & 1.3200 & 0.0298 \\
Bank performance related Variables & 3 & 3.0003 & 0.0001 & 0.5800 & 0.0001 \\
Bank performance related Variables & 4 & 4.0070 & 0.0017 & 0.9000 & 0.0019 \\
\hline
\end{tabular}

\section{Findings}

We first present the findings of paired comparison of trust variable indices in Table 2 as follows,

Table 2

Individual Variable

\begin{tabular}{cccc}
\hline Priorities & $1^{\text {st }}$ Priority & $2^{\text {nd }}$ priority & $3^{\text {rd }}$ priority \\
\hline Variable & Attitudinal & Personality & Skills \\
Weight & 0.362 & 0.343 & 0.296 \\
\hline
\end{tabular}

As we can observe from the results of Table 2, the attitudinal factor is number one priority followed by personality factor and the skills factor. Similarly, Table 3 shows details of banking variables. As we can observe from the results of Table 3, Security system is number one followed by being error free and professionalism. In terms of website characteristics, Table 4 shows details of our ranking. Table 5 shows the aggregate results of paired comparison of banking factors: 
Table 3

Banking variable

\begin{tabular}{|c|c|c|c|c|c|c|c|}
\hline Priorities & $1^{\text {st }}$ priority & $2^{\text {nd }}$ priority & $3^{\text {rd }}$ priority & $4^{\text {th }}$ priority & $5^{\text {th }}$ priority & $6^{\text {th }}$ priority & $7^{\text {th }}$ priority \\
\hline Factor & $\begin{array}{l}\text { Security } \\
\text { system }\end{array}$ & Error free & Professionalism & $\begin{array}{l}\text { Ease of } \\
\text { access }\end{array}$ & $\begin{array}{l}\text { User } \\
\text { friendly }\end{array}$ & Assurance & $\begin{array}{l}\text { Customer } \\
\text { oriented }\end{array}$ \\
\hline Weight & 0.271 & 0.247 & 0.101 & 0.0969 & 0.0963 & 0.0967 & 0.08973 \\
\hline
\end{tabular}

Table 4

The results of ranking of website components

\begin{tabular}{llll}
\hline Priorities & $1^{\text {st }}$ priority & $2^{\text {nd }}$ priority & $3^{\text {rd }}$ priority \\
\hline Factor & Competency \& reputation & Creativity \& Innovation & predictability \\
Weight & 0.433 & 0.365 & 0.202 \\
\hline
\end{tabular}

Table 5

The results of aggregate factors

\begin{tabular}{lll}
\hline Priorities & $1^{\text {st }}$ priority & $2^{\text {nd }}$ priority \\
\hline Factor & Bank Performance & Website \\
Weight & 0.6197 & 0.3803 \\
\hline
\end{tabular}

The results derived from the paired comparisons of banking factors show that e-customers signify the bank's website more important than bank performance. In addition, Table 6 shows details of ranking for infrastructural variable.

Table 6

The results of the AHP implementation for infrastructural

\begin{tabular}{lcccc}
\hline Priorities & $1^{\text {st }}$ priority & $2^{\text {nd }}$ priority & $3^{\text {rd }}$ priority & $4^{\text {th }}$ priority \\
\hline Factor & Telecommunication & Cultural & Financial & Legal \\
Weight & 0.2993 & 0.2901 & 0.2381 & 0.1726 \\
\hline
\end{tabular}

The findings of the study indicate that the factor of telecommunication infrastructure is the first priority, followed by cultural, financial and legal affairs. Table 7 shows the overall ranking of different factors associated with banking, infrastructural and individual.

Table 7

The results of ranking of banking, infrastructure and individual factors

\begin{tabular}{lccc}
\hline Priorities & $1^{\text {st }}$ priority & $2^{\text {nd }}$ priority & $3^{\text {rd }}$ priority \\
\hline Factor & Banking & Infrastructural & Individual \\
Weight & 0.380 & 0.355 & 0.265 \\
\hline
\end{tabular}

The results of Table 7 indicate that banking issues have received the highest priority followed by infrastructural and individual issues.

\section{Conclusion and discussion}

The findings indicate that the Individual factor influenced the e-customers trust for $26 \%$, the banking factor for $38 \%$ and the infrastructure factor influenced the e-customers trust in Persian Bank for 35\%. As presented the banking factor gained 0.38 and possess the highest position (priority) among the main factors. In terms of indices associated with the attitude factor (0.36), telecommunication 
infrastructure and cultural factor (0.29) possess the highest influence and the factors of customerorientation (0.08) and for the case of the access, assurance and user friendly (0.09) place in the lowest positions. Fig. 2 shows the summary of the findings of the proposed study of this paper.

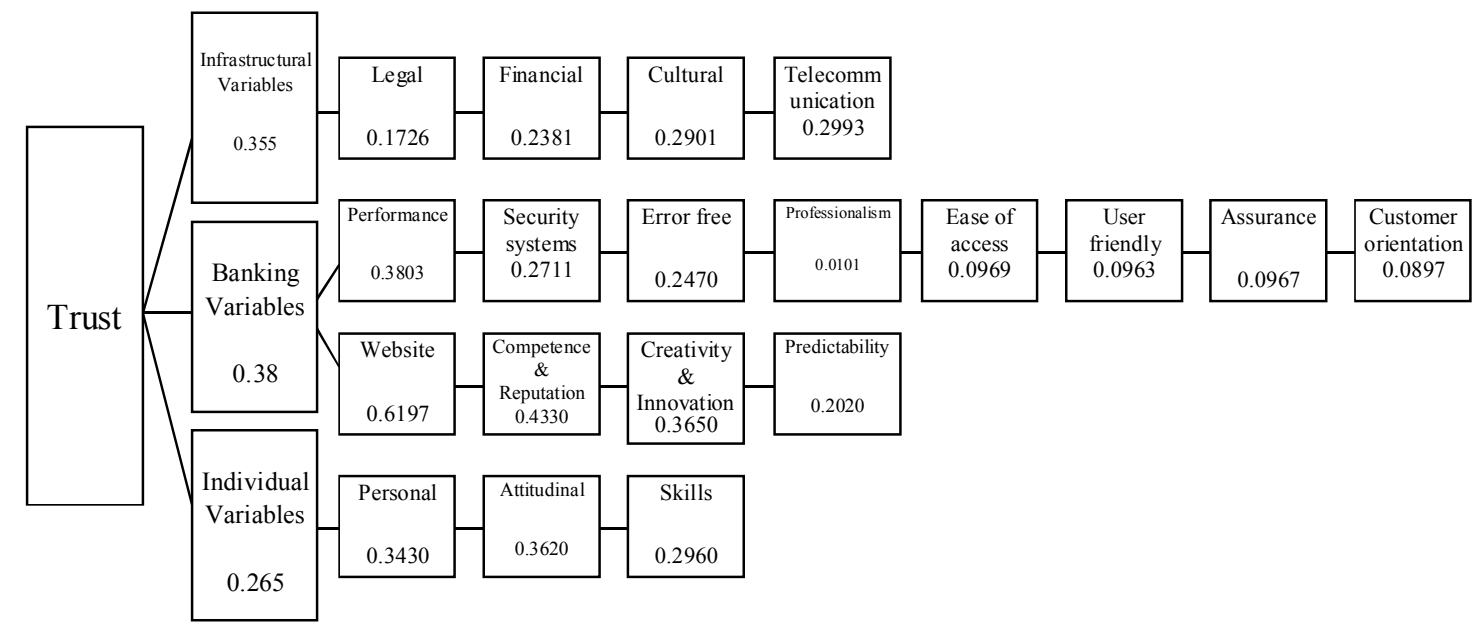

Fig. 2. The results of ranking of the study

\section{Acknowledgement}

The authors would like to thank the anonymous referees for constructive comments on earlier version of this paper.

\section{References}

Ang, L., Dubelaar, C., \& Lee, B. (2001, June). To trust or not to trust? A model of internet trust from the customer's point of view. In Proc. 14th Bled E-Commerce Conf (pp. 25-26).

Bailey, T. (2002). On trust and philosophy. The Philosophy of Trust.

Corbitt, B. J., Thanasankit, T., \& Yi, H. (2003). Trust and e-commerce: a study of consumer perceptions. Electronic commerce research and applications, 2(3), 203-215.

Egger, F. N. (2000, April). Trust me, I'm an online vendor: towards a model of trust for e-commerce system design. In CHI'00 extended abstracts on Human factors in computing systems (pp. 101102). ACM.

Geffen, D., \& Govindaraiulu, C. (2001). ERP customer loyalty: an exploratory investigation into the importance of a trusting relationship. Journal of Information Technology Theory and Application (JITTA), 3(1), 3.

Hemphill, T. A. (2002). Electronic commerce and consumer privacy: Establishing online trust in the US digital economy. Business and Society Review, 107(2), 221-239.

Kotler, P., \& Armstrong, G. (2010). Principles of marketing. Pearson Education.

Lee, M. K., \& Turban, E. (2001). A trust model for consumer internet shopping. International Journal of electronic commerce, 6, 75-92.

Mayer, R. C., Davis, J. H., \& Schoorman, F. D. (1995). An integrative model of organizational trust. Academy of management review, 20(3), 709-734.

Rousseau, D. M., Sitkin, S. B., Burt, R. S., \& Camerer, C. (1998). Not so different after all: A crossdiscipline view of trust. Academy of management review, 23(3), 393-404.

Saaty, T. L. (1994). Highlights and critical points in the theory and application of the analytic hierarchy process. European Journal of Operational Research,74(3), 426-447.

Urban, G. L., Sultan, F., \& Qualls, W. J. (2000). Placing trust at the center of your internet strategy. Sloan Management Review, 42(1), 39-48. 
Shankar, V., Urban, G. L., \& Sultan, F. (2002). Online trust: a stakeholder perspective, concepts, implications, and future directions. The Journal of strategic information systems, 11(3), 325-344.

Wang, Y. D., \& Emurian, H. H. (2005). An overview of online trust: Concepts, elements, and implications. Computers in human behavior, 21(1), 105-125.

Wan, W. W., Luk, C. L., \& Chow, C. W. (2005). Customers' adoption of banking channels in Hong Kong. International Journal of bank marketing, 23(3), 255-272.

Yoon, S. J. (2002). The antecedents and consequences of trust in online-purchase decisions. Journal of interactive marketing, 16(2), 47-63. 